$\begin{array}{ll}\text { Abstracta Iranica } & \begin{array}{l}\text { Abstracta Iranica } \\ \text { Revue bibliographique pour le domaine irano-aryen }\end{array} \\ & \text { Volume } \mathbf{2 9 |} \mathbf{2 0 0 8} \\ & \text { Comptes rendus des publications de } \mathbf{2 0 0 6}\end{array}$

\title{
Christ in the East syriac Tradition. Satna (Inde), Ephrem, 2003, 213 p.
}

\section{Christelle Jullien}

\section{(2) OpenEdition}

1 Journals

\section{Édition électronique}

URL : http://journals.openedition.org/abstractairanica/30142

DOI : 10.4000/abstractairanica.30142

ISSN : 1961-960X

Éditeur :

CNRS (UMR 7528 Mondes iraniens et indiens), Éditions de l'IFRI

\section{Édition imprimée}

Date de publication : 15 mai 2008

ISSN : 0240-8910

\section{Référence électronique}

Christelle Jullien, «Christ in the East syriac Tradition. Satna (Inde), Ephrem, 2003, 213 p. », Abstracta Iranica [En ligne], Volume 29 | 2008, document 280, mis en ligne le 15 septembre 2008, consulté le 26 septembre 2020. URL : http://journals.openedition.org/abstractairanica/30142 ; DOI : https://doi.org/ 10.4000/abstractairanica.30142

Ce document a été généré automatiquement le 26 septembre 2020.

Tous droits réservés 


\title{
Christ in the East syriac Tradition. Satna (Inde), Ephrem, 2003, 213 p.
}

\author{
Christelle Jullien
}

Dans un premier chapitre, l'A. s'intéresse à l'histoire chrétienne des Églises orientales syriaques, reprenant les données des traditions sur l'apôtre Thomas chez les chrétiens de Mésopotamie et d'Inde. Il présente par ailleurs une vue globale sur les mouvements uniates jusqu'à nos jours au sein de ces communautés. Le second volet concerne plutôt les mouvements christologiques de ces régions syro-orientales de l'empire iranien, depuis le IV $\mathrm{s}$. L'A. donne une introduction générale à l'ouvrage de Nestorius, le Livre d'Héraclide, dans laquelle il réévalue les positions dites "nestoriennes" de l'Eglise d'Orient. Sont reprises ici les positions qu'avait défendues S. P. Brock dans un article qui fit date, "The 'nestorian' Church: a lamentable misnomer », Bulletin of the John Rylands University Library of Manchester 78/3, 1996, pp. 23-35. Les chapitres suivants concernent davantage l'histoire ecclésiastique récente, notamment les avancées christologiques et le dialogue entre les Églises orientales et latine, depuis le concile Vatican II.

INDEX

Thèmes : 6.3. Autres religions 
AUTEURS

CHRISTELLE JULLIEN

CNRS - Mondes iranien et indien - Paris 